\title{
IN-FURROW STARTER AND BROADCAST PHOSPHORUS AND POTASSIUM FERTILIZATION FOR CORN
}

\author{
Daniel E. Kaiser, Antonio P. Mallarino, and Manuel Bermudez \\ Department of Agronomy, Iowa State University
}

\section{Introduction}

Increasing awareness of potential impacts of farming on the environment has renewed interest in further study of fertilizer management strategies that reduce nutrient inputs. Fertilizer recommendations for phosphorus $(\mathrm{P})$ and potassium $(\mathrm{K})$ usually are based on soil-test values and nutrient removal with crop harvest. Many Midwest farmers follow these recommendations, but many others apply removal-based $\mathrm{P}$ and $\mathrm{K}$ fertilizer rates even in high-testing soils. The typical farmer applies $\mathrm{P}$ and $\mathrm{K}$ fertilizer for a corn-soybean rotation as a single broadcast application before the corn crop. Some farmers, mainly in northern areas or those using no-tillage practices, also apply small starter fertilizer rates for corn because they are concerned about reduced early growth commonly seen with such practices.

Many studies have shown that starter fertilization can increase early corn growth, nutrient uptake, and grain yield. Research has also shown that band application of small amounts of $\mathrm{P}$ and $\mathrm{K}$ fertilizers are more efficient than similar rates applied broadcast. Little research has focused on studying how starter $\mathrm{P}$ and $\mathrm{K}$ rates can supplement larger broadcast rates, such as those used for a 2-year rotation. The role of starter fertilization and its benefits could be different in these conditions. Starter fertilization could supplement broadcast $\mathrm{P}$ and $\mathrm{K}$ rates applied to low-testing soils when high concentrations of these nutrients are needed near young roots. On the other hand, small starter fertilizer rates could be sufficient to attain maximum yield of one crop in soils testing near optimum in $\mathrm{P}$ and $\mathrm{K}$. To test these possibilities, this on-farm study assessed the response of corn grain yield, early growth, and early $\mathrm{P}$ and $\mathrm{K}$ uptake to in-furrow liquid starter fertilization compared with responses to broadcast $\mathrm{P}$ and $\mathrm{K}$ fertilization rates commonly used by farmers.

\section{Materials and Methods}

Thirteen trials were established over a period of 3 years in Iowa farmers' fields varying in soiltest $\mathrm{P}$ and $\mathrm{K}$ values, soils, and tillage system. Five fields were managed with no-tillage and the others were managed with chisel-plow tillage. Treatments were a control, a commercial liquid starter mixture (3-18-18 N-P $\mathrm{O}_{5}-\mathrm{K}_{2} \mathrm{O}$ ) applied in the furrow, broadcast $\mathrm{P}$ and $\mathrm{K}$, and broadcast $\mathrm{P}$ and $\mathrm{K}$ plus starter. The $\mathrm{P}$ and $\mathrm{K}$ starter rates applied were 10 to $14 \mathrm{lb} / \mathrm{acre}$ of $\mathrm{P}_{2} \mathrm{O}_{5}$ and $\mathrm{K}_{2} \mathrm{O}$. Broadcast $\mathrm{P}$ and $\mathrm{K}$ fertilizers were applied for corn as a single application of the average $\mathrm{P}$ and $\mathrm{K}$ removed in corn and soybean grain. Phosphorus rates were 100 to $110 \mathrm{lb}_{2} \mathrm{O}_{5} /$ acre across sites, and the $\mathrm{K}$ rate was $120 \mathrm{lb} \mathrm{K}_{2} \mathrm{O}$ /acre. Plots at each trial measured $50 \mathrm{ft}$ in length and 15 to $23 \mathrm{ft}$ in width (depending on the width of the planter used). Four replications were arranged as a randomized complete-block design. The producers applied 107 to $134 \mathrm{lb} \mathrm{N} / \mathrm{acre}$, and a rate of 60 $\mathrm{lb}$ N/acre was applied by hand at planting time. 
Soil samples ( 0 to 6 inch depth) were collected before applying the treatments. Iowa State University soil-test interpretation classes are used in this article (Sawyer et al., 2002). The classes for the Bray-1 P test are 0-8 ppm Very Low, 9-15 Low, 16-20 Optimum, 21-30 High, and $>30$ Very High. The classes for the ammonium-acetate K test are 0-90 ppm Very Low, 91-130 Low, 131-170 Optimum, 171-200 High, and >200 Very High. The above-ground portions of 10 plants were collected from each plot at the V5-V6 growth stage, dried, weighed, and analyzed for total $\mathrm{P}$ and $\mathrm{K}$ concentration. The grain was hand harvested, and yield was adjusted to $15.5 \%$ moisture content.

\section{Summary Results}

Fertilization increased corn grain yield significantly $(P .0 .05)$ in five sites. The treatments differed only in one site, where the broadcast and broadcast plus starter treatments increased yield more than the starter treatment. Soil-test $\mathrm{P}$ was below Optimum at four responsive sites and was High at one site, whereas soil-test $\mathrm{K}$ varied from Low to High. At the site where the treatments differed, soil-test P was Very Low and soil-test K was Low. Either soil-test P or K were below Optimum in three non-responsive sites. Corn hybrid, tillage system, planting date, and seasonal weather did not clearly affect corn yield responses, although the responsive site with a High soil-test $\mathrm{P}$ value was managed with no-tillage. Previous Iowa research with no-till corn and other starter fertilizer mixtures (Bermudez and Mallarino, 2002) also had shown no clear effects of hybrid, planting date, and rainfall on yield response. However, Bundy and Andraski (1999) observed that the probability of corn response to starter fertilizer mixtures in Wisconsin increased for later planting dates and hybrids of long relative maturity.

Results for early growth responses were a sharp contrast to results for yield response. Early corn growth was increased in 9 of 11 sites sampled. The two non-responsive sites tested above Optimum in both $\mathrm{P}$ and $\mathrm{K}$, but growth responses were observed in other high-testing soils. The fertilizer treatments differed in six sites. The starter was better than the broadcast fertilization at four sites, the broadcast was better than the starter at one site, and the starter plus broadcast was better that either method used alone at one site. The tillage system, soil-test values, planting date, rainfall, or air temperature could not clearly explain treatment differences.

Fertilization seldom influenced early plant $\mathrm{P}$ concentration but increased early $\mathrm{P}$ uptake in onehalf of the sites, mainly because of increased early growth. Treatments sometimes differed, but differences were not consistent across trials and could not be explained with the methods used. In contrast to results for $\mathrm{P}$, fertilization usually increased early plant $\mathrm{K}$ concentration and uptake. The two non-responsive sites tested Very High and one tested Optimum in soil-test K. The broadcast and starter treatments differed at six sites. The starter treatment was better in three sites and the broadcast was better in the other three sites. The tillage system, soil-test values, planting date, or rainfall could no clearly explain these treatment differences. However, the larger and more frequent response of early plant $\mathrm{K}$ concentration compared with early $\mathrm{P}$ concentration agreed with previous Iowa research using other placement methods (Mallarino et al., 1999; Borges and Mallarino, 2001).

The results of this study indicated that a very small amount of starter fertilizer applied to the seed furrow produced larger early growth and early nutrient uptake than much larger broadcast 
fertilization rates. This result is shown in Figure 1, which describes the average responses across sites for various measurements. However, large and frequent corn early growth responses to starter fertilization were not good indicators of grain yield response. Also, larger and more frequent early $\mathrm{K}$ uptake response to fertilization compared with early $\mathrm{P}$ uptake did not explain grain yield responses and indicated luxury accumulation of $\mathrm{K}$.
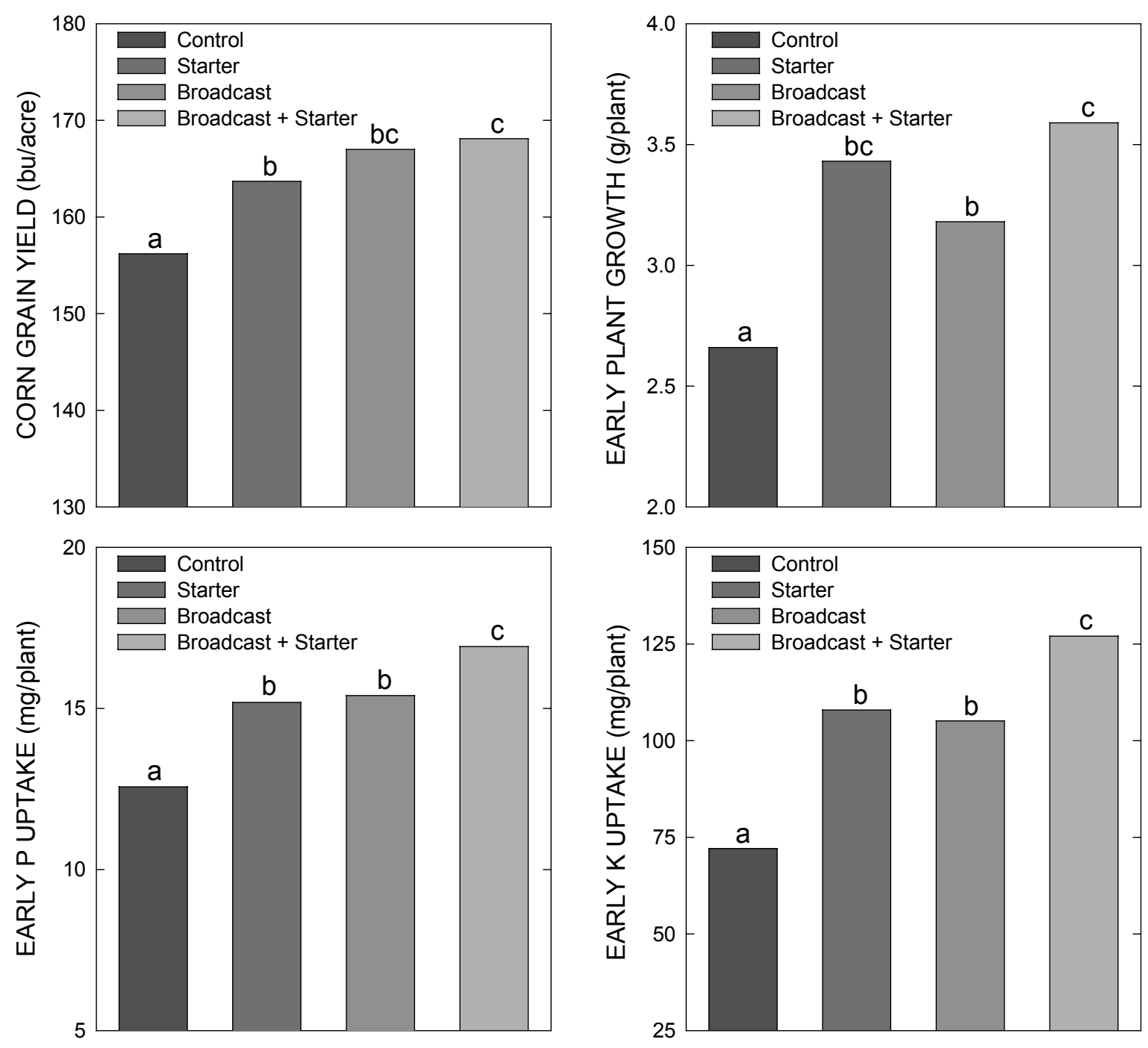

Figure 1. Average response of corn grain yield, early growth, and early $\mathrm{P}$ or $\mathrm{K}$ uptake to infurrow starter and broadcast $\mathrm{P}$ and $\mathrm{K}$ fertilization across 13 on-farm trials in Iowa. Different letters within a graph indicate significant differences at $P<0.05$.

\section{Conclusions}

In the short term, a small amount of starter fertilizer applied to the seed furrow can produce similar yield levels as much larger broadcast rates, except when soil nutrient levels are Very Low. However, starter application in addition to broadcast fertilizer rates commonly applied before corn for the 2-year corn-soybean rotation do not increase yield further. Fertilization increased yield only in one high-testing soil, and a small starter fertilizer rate or a removal-based 
broadcast P-K rate produced similar yield levels. Thus, use of starter fertilizer provides a more economical and environmentally sound way of applying $\mathrm{P}$ and $\mathrm{K}$ when a farmer is concerned about reduced early corn growth and possible yield loss under some conditions in high-testing soils.

\section{References}

Bermudez, M., and A.P. Mallarino. 2002. Yield and early growth responses to starter fertilizer in no-till corn. Agron. J. 94:1024-1033.

Borges, R., and A.P. Mallarino. 2001. Deep banding phosphorus and potassium fertilizers for corn produced under ridge tillage. Soil Sci. Soc. Am. J. 65:376-384

Bundy, L.G. and T.W. Andraski. 1999. Site-specific factors affecting corn response to starter fertilizer. J. Prod. Agric. 12:664-670.

Mallarino, A.P., J.M.. Bordoli, and R. Borges. 1999. Phosphorus and potassium placement effects on early growth and nutrient uptake of no-till corn and relationships with grain yield. Agron. J. 91:37-45.

Sawyer, J.E., A.P. Mallarino, R. Killorn, and S.K. Barnhart. 2002. General guide for crop nutrient recommendations in Iowa. Publ. Pm-1688 (Rev.). Iowa State Univ. Extension. 